\title{
Black American and Latinx Parent/Caregiver Participation in Digital Health Obesity Interventions for Children: A Systematic Review
}

\author{
Jennifer Sanchez-Flack 1,2,3*, Joanna Buscemi ${ }^{4}$, Alexander O'Donnell ${ }^{4}$, \\ Margaret $\mathrm{H}$. Clark Withington ${ }^{4}$ and Marian Fitzgibbon ${ }^{1,2,3}$
}

${ }^{1}$ Department of Pediatrics, University of Illinois at Chicago, Chicago, IL, United States, ${ }^{2}$ University of Illinois Cancer Center, University of Illinois at Chicago, Chicago, IL, United States, ${ }^{3}$ Institute for Health Research and Policy, University of Illinois at Chicago, Chicago, IL, United States, ${ }^{4}$ Department of Psychology, DePaul University, Chicago, IL, United States

OPEN ACCESS

Edited by:

Colleen Stiles-Shields, Rush University Medical Center,

United States

Reviewed by:

Elvin Thomaseo Burton, University of Tennessee Health

Science Center (UTHSC),

United States

Gloria Cosoli,

Marche Polytechnic University, Italy

Melissa Santos,

Connecticut Children's Medical

Center, United States

*Correspondence:

Jennifer Sanchez-Flack

jsanch38@uic.edu

Specialty section:

This article was submitted to

Connected Health,

a section of the journal

Frontiers in Digital Health

Received: 29 March 2021

Accepted: 18 May 2021

Published: 15 June 2021

Citation:

Sanchez-Flack J, Buscemi J,

O'Donnell A, Clark Withington MH and

Fitzgibbon M (2021) Black American and Latinx Parent/Caregiver

Participation in Digital Health Obesity Interventions for Children: $A$

Systematic Review.

Front. Digit. Health 3:687648. doi: 10.3389/fdgth.2021.687648
Parents/caregivers are consistently described as integral targets given their influential role in supporting and managing behaviors such as diet and physical activity. Identifying effective obesity prevention interventions to enhance and sustain parent participation is needed. Digital obesity prevention interventions are a promising strategy to improve parent/caregiver participation. Digital health interventions demonstrate acceptable participation and retention among parents/caregivers. However, our understanding of digital obesity prevention interventions targeting Black American and Latinx parents/caregivers is limited. This systematic review aims to identify Black American and Latinx parents'/caregivers' level of participation in digital obesity prevention and treatment interventions and determine the relationship between parent/caregiver participation and behavioral and weight status outcomes. This review adheres to PRISMA guidelines and is registered in PROSPERO. Eligibility criteria include: intervention delivered by digital technology, targeted Black American and Latinx parents/caregivers of young children (2-12 years), reported parent/caregiver participation outcomes, targeted diet or physical activity behaviors, and randomized controlled trial study design. Searches were conducted in September 2020 in ERIC, PsychInfo, PubMed, and Web of Science. Initial searches returned 499 results. Four reviewers screened records against eligibility criteria and 12 studies met inclusion criteria. Across all studies, parent/caregiver participation ranged from low to high. Only half of the included studies reported significant improvements in behavioral or weight status outcomes for parents/caregivers and/or children. Of these studies, three reported high parental/caregiver participation rates, and three reported high satisfaction rates. These findings suggest that participation and satisfaction may impact behavior change and weight status. The small number of studies indicates that additional research is needed to determine whether engagement or other factors predict responsiveness to the digital health intervention. Our results lay the groundwork for developing and testing future digital health interventions with the explicit goal of parental/caregiver participation and considers the need to expand our digital health intervention research methodologies to address obesity inequities among diverse families better.

Keywords: digital health, obesity, health inequities, behavioral interventions, systematic review 


\section{INTRODUCTION}

Younger generations have earlier and longer exposure to excess adiposity over their lifetime compared to previous generations (1). This longer-term exposure to excess adiposity is problematic. Additionally, obesity is associated with hypertension (2), type 2 diabetes (3), coronary heart disease (CHD) (4), stroke (5), and osteoarthritis (6) among other chronic conditions. Recent evidence demonstrates that obesity and an obesogenic diet accelerates the transition of tissue from normal to invasive malignancy and metastatic disease $(7,8)$. Recent data demonstrates that obesity prevalence for youth (aged 2-19 years old) is $18.5 \%$; with obesity prevalence among preschoolaged children ( $2-5$ years) at 13.9 and $18.4 \%$ among schoolaged children (6-11 years) (9). Additionally, obesity inequities exist, and racially/ethnically diverse children have higher rates of obesity than non-Latinx Whites. For example, $19.5 \%$ of Black American and $21.9 \%$ of Latinx children have obesity, compared to $14.7 \%$ of non-Latinx White children (10).

Strategies to prevent and treat childhood obesity include the promotion of healthy dietary and physical activity behaviors. The promotion of such behaviors is important because of the low dietary quality and increased physical inactivity of children in the United States, which is contributing to the overweight and obesity risk, the increased risk younger generations are facing for six of the 12 obesity-related cancers, and increased risk of chronic conditions such as CHD in adulthood (11, 12). The dietary quality of children has worsened in recent decades with data showing a low consumption of fruit and vegetables, whole grains, and fish and a high consumption of sodium and sugar-sweetened beverages among children (13). Similarly, children in the United States do not meet recommended guidelines for physical activity, with only half engaging in the recommended 60-min of physical activity per day (14). Currently, underserved children, such as Black American and Latinx children, demonstrate poorer dietary and physical activity patterns, as compared to non-Latinx White children, which may explain their disproportionate rates of obesity. Young children from minority and low-income communities do not meet USDA recommended dietary guidelines (15-18). For example, the California Health Interview Survey study found that Black American and Latinx children consumed more sugarsweetened beverages, fruit juice and fast food consumption and consumed less fruits and vegetables compared to non-Latinx White children (19). Underserved children also do not meet recommended guidelines for physical activity, with only half engaging in the recommended 60-min of physical activity per day (14) and low-income Latinx children exhibiting the lowest rates of physical activity (20). Therefore, preventing or treating overweight/obesity earlier, by promoting healthier behaviors, can help reduce the lifetime risk of overweight, obesity, and obesityrelated chronic diseases (21).

Children are primarily socialized within the family environment, with parents/caregivers serving as gatekeepers to lifestyle behaviors (22). Given the family's highly influential role in supporting and managing lifestyle behaviors, parents/caregivers are integral targets in health behavior interventions (23-25). Recent systematic reviews report that obesity prevention interventions for young children result in more positive changes in both weight status and obesity-related behaviors when they include a parent/caregiver participation component, compared to interventions that do not $(26,27)$. However, in previous obesity prevention interventions with a parent/caregiver participation component, participation has been low, but nonetheless positively associated with successful changes in children's behavior (28-30). Commonly cited barriers to participation include time constraints, lack of childcare, and lack of transportation (28-31). Therefore, effective, and efficacious obesity prevention interventions including parents/caregivers are urgently needed.

Digital health interventions (DHI) are a promising strategy to improve and maintain Black American and Latinx parent participation in obesity prevention interventions. Approximately 96\% of Americans, including racially/ethnically diverse and lowincome populations, own a smartphone or a cellphone, with smartphone ownership being more common (32). Additionally, Black American and Latinx populations rely more heavily on smartphones for online access or are "smartphone only" internet users, meaning they lack traditional home broadband service but do own a smartphone, compared to non-Latinx White populations $(32,33)$. Therefore, traditional in-person evidencebased interventions could be adapted to be digital delivery (e.g., text messages, websites, or mobile applications) to enhance participation in obesity prevention or treatment programs (34). Recent internet- and mobile-based interventions show acceptable participation (used DHI at least one time/week) (35) and retention (above $80 \%$ retention rate at post-intervention) among parents/caregivers with young children $(36,37)$. Although the number of DHIs among parents/caregivers of Black American and Latinx young children is limited, there is a need to systematically evaluate this body of literature to (1) determine the effectiveness of DHIs and (2) the relationship between parent/caregiver participation and behavioral and health outcomes for both parents/caregivers and children. The primary aim is to identify Black American and/or Latinx parents'/caregivers' level of participation in DHIs for obesity prevention or treatment for their children. The secondary aim is to determine the relationship between parent/caregiver participation and behavioral (diet and physical activity) and health outcomes for both parents/caregivers and children.

\section{METHODS}

\section{Study Design}

The systematic reviews adheres to the Preferred Reporting Items for Systematic Reviews and Meta-Analyses (PRISMA) (38) and is registered in PROSPERO (ID: CRD42020194390).

\section{Inclusion and Exclusion Criteria}

The search protocol was developed using the Population, Intervention, Comparison, Outcomes, and Study Design (PICOS) framework for systematic reviews (38). A study was included if: it was peer-reviewed, a randomized-controlled trial, a DHI targeting obesity prevention and/or treatment, participants 
were primarily Black American and/or Latinx (at least 25\% of the study sample), included young children aged 2-12 (39) and their parents/caregivers, included measured outcomes of parent participation (e.g., user-reported interaction with the DHI through self-report questionnaires, interviews) $(40,41)$, and measured outcomes of dietary intake, physical activity, and/or weight status. For the purposes of this review, to meet the definition of a DHI, interventions had to use digital technology to promote and/or maintain health, including web-based strategies, mobile health applications, text messaging, automated healthcare and communication systems, or a combination of these digital technology strategies (42). Studies were excluded if they were not published in English and were not peer-reviewed.

\section{Search Strategy}

Searches were conducted in ERIC, PsycINFO, PubMed, and Web of Science in September 2020. The search strategy was developed in consultation with and reviewed by an experienced university librarian. All search histories were documented in an Excel spreadsheet, which contained data regarding the database searched, filters, number of records retrieved and number of duplicates. Search strings corresponded to the following six terms: (1) obesity; (2) diet; (3) physical activity; (4) digital health; (5) parents; and (6) race/ethnicity and were limited to randomized controlled trials. Searches were not limited by publication date. The full search strategy for all databases is presented in Supplementary Material 1.

\section{Selection and Screening}

All citations were imported into RefWorks for identification of duplicates. In RefWorks, separate folders were created for each database searched. First, internal duplicates (duplicates within the same database) were identified. Second, external duplicates (duplicates within separate databases) were identified and reported. Duplicates not identified within RefWorks, were identified in Covidence-a program developed for managing systematic review title/abstract and full text screening and data extraction (Covidence systematic review software, Veritas Health Innovation, Melbourne, Australia. Available at www.covidence.org). Figure 1 illustrates the search strategy and screening process in more detail. Initial searches resulted in 499 records and after the removal of duplicates, 368 records were included for screening in Covidence. Three reviewers (JSF, $\mathrm{AO}$, and MW) independently screened records against eligibility screening in two phases: (1) title and abstract and (2) full text. In both screening phases, JSF screened all records and $\mathrm{AO}$ and MW screened $50 \%$ of records. Any discrepancies were resolved by an additional reviewer (JB). If an abstract was missing for any citation, the article continued onto full text screening. During title and abstract screening, 327 records were excluded, which resulted in 41 full text articles to be assessed for inclusion. Upon completion of full text of screening, 29 were excluded resulting in 12 studies to be included.

\section{Data Extraction and Synthesis}

Data were extracted into a form developed by JSF. The data extraction form was determined at the outset of the study, based on study aims, and the form was piloted on a small sample of studies. Then, JSF extracted $100 \%$ of the data, AO extracted data from $50 \%$ of studies and MW extracted data from the other $50 \%$ of studies. When data extraction was completed, JB compared all extracted data and resolved all discrepancies, which were identified in Covidence as highlighted data extraction discrepancies between JSF, AO, and MW. The following information was extracted: author, year of publication, city/state/country, setting, sample size, participant characteristics (e.g., age, race/ethnicity, inclusion, and exclusion criteria), type of DHI (e.g., web-based, text message), brief description of DHI, DHI duration, diet and/or physical activity behavioral outcome measures, parent/caregiver participation measures, parent/caregiver participation outcomes, retention rate/withdrawals/loss to follow-up, diet and/or physical activity outcomes for parent/caregiver and/or child. The categories for data extraction were kept broad because of methodological differences across studies (43). A narrative synthesis, specifically a textual narrative synthesis, of studies meeting the inclusion criteria was conducted $(44,45)$. A narrative synthesis is a systematic review approach that relies primarily on the use of text to synthesize findings from multiple studies to summarize and explain findings; it is best used when statistical metaanalysis is not feasible due to considerable methodological and clinical differences between studies (46). Study characteristics, DHI strategies, measures, and findings are reported according to a standard format and similarities and differences are compared across studies (47). Bias ratings were conducted in accordance with the guidelines of the Cochrane risk of bias assessment tool (48), which outlines qualifications for high, low, or unclear risk of bias.

\section{RESULTS}

\section{Description of Studies, DHI Strategies, and Dose}

Study design characteristics, including a brief description of the DHI, sample size and description, study duration and DHI dose, and outcome measures are reported in Table 1. Of the 12 studies, all were conducted in the United States, the sample sizes for the studies ranged from 27 to 721 participants or parent/child dyads, the age range of children included in the studies was between 2 and 15 years old, and study duration ranged from 3 weeks to 2 years. All the included studies included Black American families in their sample and three studies included Latinx families. Of these studies, $28-100 \%$ of the study sample identified as Black American and $7-51 \%$ of the study sample identified as Latinx. The current review included both obesity prevention and treatment DHIs. Types of DHI strategies included text messages, websites, e-mails and Interactive Voice Technology (IVR). Of the included studies, four were obesity treatment interventions and recruited children with overweight and/or obesity $(49,57,59,60)$, one study was an obesity prevention intervention that recruited mothers with overweight/obesity (55), and the remaining studies were obesity prevention interventions that recruited children and parents/caregivers regardless of weight status $(50-54,56,58)$. 


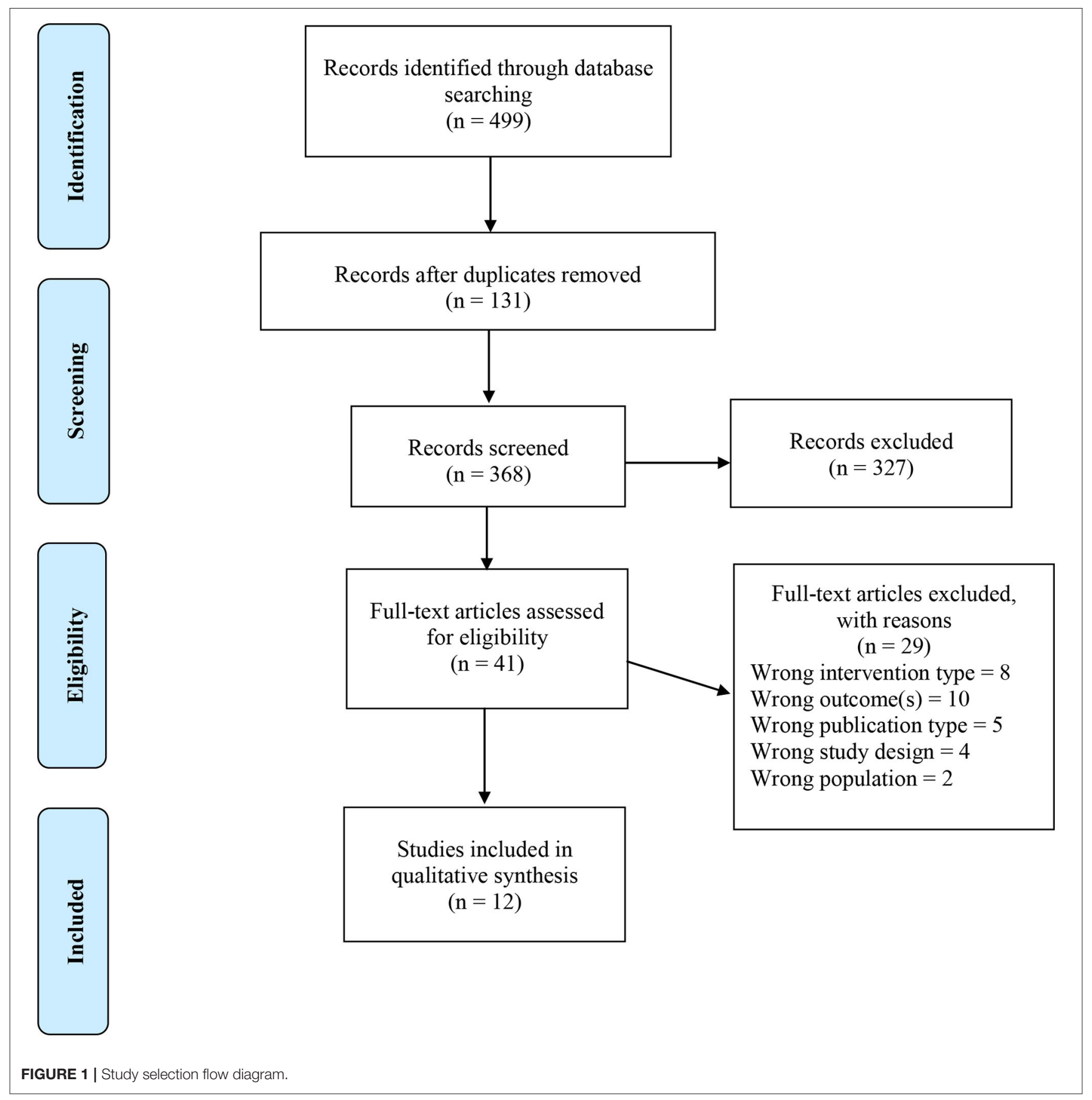

Nine studies were rated as low risk for bias (49-51, 53, 55-58, 60), two studies were rated as unclear $(52,59)$, and one study was rated as high risk (54).

Of the included studies, six used text messaging as part of their DHI $(49,53-55,57,58)$. Of these six studies, one was a text message-based only DHI and decreased the number of text messages sent to parents/caregivers over the study period from three text messages per week to 1-2 text messages sent per week (49). The remaining five studies utilized text messages in combination with another intervention strategy such as a website or e-mail communication $(54,55,57,58,61)$.
Five of the 12 studies utilized a website as part of their DHI $(50-52,54,55,59)$ and only one of these studies was a websiteonly DHI (52). Most of these studies updated the website content on a weekly basis $(n=4)(50,51,54,59)$, one study updated the website content on a weekly basis and then decreased this to a bi-weekly basis (55), while one study consisted of six, self-paced website modules (52).

Four studies used e-mail as part of their DHI strategy (50, 55, $57,59)$. Two of these studies sent e-mails to parents/caregivers on a weekly basis $(50,59)$, one study sent e-mails on a weekly basis during the first half of the DHI and then on a bi-weekly 


\begin{tabular}{|c|c|c|c|c|c|c|}
\hline $\begin{array}{l}\text { Study (Author name, } \\
\text { year, and city/state, risk } \\
\text { of bias) }\end{array}$ & Sample size & $\begin{array}{l}\text { Characteristics of } \\
\text { population }\end{array}$ & $\begin{array}{l}\text { DHI } \\
\text { methodology }\end{array}$ & Brief description of DHI & Duration and Dose & $\begin{array}{l}\text { Behavioral and } \\
\text { weight status } \\
\text { measures }\end{array}$ \\
\hline $\begin{array}{l}\text { Armstrong et al., 2018, } \\
\text { Durham, NC, USA, low risk } \\
\text { of bias ( } 49 \text { ) }\end{array}$ & $N=100$ & $\begin{array}{l}\text { Children aged } 5-12 \text { years } \\
\text { old and their } \\
\text { parent/guardian enrolling in } \\
\text { tertiary-care obesity } \\
\text { treatment. } 48 \% \text { of } \\
\text { participants identified as } \\
\text { Black American. }\end{array}$ & Text messages. & $\begin{array}{l}\text { Usual care plus daily text messages to parents. Text } \\
\text { messages consisted of } 100 \text { Motivational } \\
\text { Interviewing (MI) prompts. The week's first text } \\
\text { message persuaded parents/guardians to identify } \\
\text { and set a family health goal. Reply text messages } \\
\text { reinforced evidence-based goals that were likely to } \\
\text { lead to the reduction of child BMI. } \\
\text { Each week, parents/guardians were invited to } \\
\text { choose a new goal or continue working on the } \\
\text { previously selected goal. } \\
\text { Text messages were sent on weekdays at } 12 \mathrm{pm} \\
\text { and replies to parents' responses were twice/day } \\
\text { and sent by } 5 \text { pm. Appointment reminders were } \\
\text { sent by text } 24-48 \mathrm{~h} \text { before a scheduled usual } \\
\text { care appointment. }\end{array}$ & $\begin{array}{l}\text { Duration: } 12 \text {-weeks } \\
\text { Dose: First week } \\
\text { included three text } \\
\text { messages and three } \\
\text { parent replies. } \\
\text { Subsequent weeks } \\
\text { included } 1-2 \text { text } \\
\text { messages and } 1-2 \\
\text { parent responses. }\end{array}$ & $\begin{array}{l}\text { - Parent/Guardian: } \\
\text { Body Mass Index } \\
\text { (BMI). } \\
\text { - Child: Food } \\
\text { Frequency } \\
\text { Questionnaire (FFQ), } \\
\text { BMl, physical activity, } \\
\text { screen time. }\end{array}$ \\
\hline $\begin{array}{l}\text { Baranowski et al., 2003, } \\
\text { Houston, TX, USA, low risk } \\
\text { of bias (50) }\end{array}$ & $N=35$ & $\begin{array}{l}\text { Black American 8-year-old } \\
\text { girls attending summer } \\
\text { camp and one of their } \\
\text { parents/guardians. }\end{array}$ & $\begin{array}{l}\text { Website with email } \\
\text { reminders. }\end{array}$ & $\begin{array}{l}\text { Website consisted of weekly behavioral or } \\
\text { environmental goals for children and } \\
\text { parents/guardians. } \\
\text { Children's webiste included: (1) comic book with } \\
\text { summer camp characters who overcame barriers in } \\
\text { making lifestyle changes consistent with diet and } \\
\text { physical activity goals; (2) problem solving for diet } \\
\text { and physical activity barriers; (3) review of previous } \\
\text { week's goals; (4) opportunities to set new diet } \\
\text { and/or physical activity goals; (5) photo album from } \\
\text { the camp; (6) ask the expert feature; and (7) links to } \\
\text { various websites. } \\
\text { If children did not click on a webpage item within } \\
\text { 10-s, items on the page began to flash, to } \\
\text { encourage a click. } \\
\text { Parent/Guardian website included: (1) comic book } \\
\text { where a character commented on each frame of the } \\
\text { child's comic; (2) a poll regarding the best methods } \\
\text { to support lifestyle changes in their children with } \\
\text { feedback from all parents the following week; (3) } \\
\text { opportunity to set a goal to help their children make } \\
\text { a lifestyle change each week; (4) review of previous } \\
\text { week's goal attainment for parents and children; (5) } \\
\text { ask the expert feature; (6) links to various websites; } \\
\text { (7) link to their child's website. }\end{array}$ & $\begin{array}{l}\text { Duration: Summer, } \\
\text { July-August } \\
\text { - Dose: Website } \\
\text { updated and e-mail } \\
\text { reminders } \\
\text { sent weekly. }\end{array}$ & $\begin{array}{l}\text { - Child: 24-h dietary } \\
\text { recall, accelerometer, } \\
\text { physical activity } \\
\text { questionnaire, waist } \\
\text { circumference, body } \\
\text { fat percentage (DEXA } \\
\text { scan), BMI. }\end{array}$ \\
\hline
\end{tabular}




\begin{tabular}{|c|c|c|c|c|c|c|}
\hline $\begin{array}{l}\text { Study (Author name, } \\
\text { year, and city/state, risk } \\
\text { of bias) }\end{array}$ & Sample size & $\begin{array}{l}\text { Characteristics of } \\
\text { population }\end{array}$ & $\begin{array}{l}\text { DHI } \\
\text { methodology }\end{array}$ & Brief description of DHI & Duration and Dose & $\begin{array}{l}\text { Behavioral and } \\
\text { weight status } \\
\text { measures }\end{array}$ \\
\hline $\begin{array}{l}\text { Cullen et al., 2017, } \\
\text { Houston, TX, USA, low risk } \\
\text { of bias (51) }\end{array}$ & $N=126$ & $\begin{array}{l}\text { Black American families with } \\
\text { 8-12-year-old children, with } \\
\text { access to a home computer } \\
\text { with high-speed Internet. }\end{array}$ & $\begin{array}{l}\text { Website with video } \\
\text { stories. }\end{array}$ & $\begin{array}{l}\text { The } 8 \text { stories follow an Black American family with } \\
\text { two } 8-12 \text {-year-old children as they try to develop } \\
\text { healthier dietary habits. After viewing the video story, } \\
\text { parents/guardians set a goal for the next week and } \\
\text { viewed a family food problem. Parents/Guardians } \\
\text { provided their opinion on how to solve the food } \\
\text { problem via a website poll. The following week, } \\
\text { parents/guardians viewed poll results and recorded } \\
\text { whether they met their goal. Session content and } \\
\text { recipes could be downloaded from the website. } \\
\text { Session content included: (1) deciding behavior } \\
\text { change; (2) getting started; (3) menu planning at } \\
\text { home; (4) eating away from home; (5) recipe } \\
\text { modification; (6) grocery shopping; (7) healthy food } \\
\text { prep practices; (8) maintaining healthy family } \\
\text { eating habits. }\end{array}$ & $\begin{array}{l}\text { Duration: 2-months. } \\
\text { - Dose: Weekly; } \\
\text { parents/guardians } \\
\text { could only view one } \\
\text { session/week but } \\
\text { could view other } \\
\text { materials and watch } \\
\text { the video story } \\
\text { as needed. }\end{array}$ & $\begin{array}{l}\text { - Parent/Guardian: } \\
\text { Dietary behaviors, } \\
\text { home availability of } \\
\text { fruit, vegetables, } \\
\text { and high-, low-, and } \\
\text { fat-free foods. } \\
\text { - Child: Fruit and } \\
\text { vegetable intake. }\end{array}$ \\
\hline $\begin{array}{l}\text { Frenn et al., 2013, Midwest, } \\
\text { USA, unclear risk of bias } \\
\text { (52) }\end{array}$ & $N=62$ dyads & $\begin{array}{l}\text { Low- to middlle-income } 5 \text { th, } \\
7 \text { th, and } 8 \text { th grade students } \\
\text { and one parent/guardian } \\
\text { from three urban schools. } \\
28 \% \text { of students identified } \\
\text { as Black American and } 7 \% \\
\text { identified as Latinx. }\end{array}$ & Website. & $\begin{array}{l}\text { Parent/Guardian intervention: 6-modules to teach } \\
\text { parents/guardians effective authoritative parenting, } \\
\text { strategies to provide positive reinforcement for } \\
\text { healthy eating and physical activity, and role } \\
\text { modeling healthy behaviors. Opportunities to } \\
\text { participate in online discussions, websites for family } \\
\text { outings, and recipes provided on website. } \\
\text { Child intervention: Four 2-3-min videos with diverse } \\
\text { child actors from similar schools. Interactive } \\
\text { components, additional websites, and ideas on } \\
\text { recipes children could make with parent/guardian. }\end{array}$ & $\begin{array}{l}\text { Duration: 3-4 weeks. } \\
\text { - Dose: Self-paced; } \\
\text { each parent/guardian } \\
\text { module took } \\
\text { 5-10 min to } \\
\text { complete; each child } \\
\text { module took } \\
10-30 \text { min } \\
\text { to complete. }\end{array}$ & $\begin{array}{l}\text { - Parent/Guardian: } \\
\text { BMl, family support } \\
\text { for reduction in } \\
\text { dietary fat, sedentary } \\
\text { behavior, and } \\
\text { physical activity, } \\
\text { and Food/Activity } \\
\text { Parenting Practices } \\
\text { Questionnaire. } \\
\text { - Child: BMl, dietary } \\
\text { fat, physical activity. }\end{array}$ \\
\hline $\begin{array}{l}\text { Haines et al., 2013, Boston, } \\
\text { MA, USA, low risk of bias } \\
\text { (53) }\end{array}$ & $N=121$ & $\begin{array}{l}\text { Families with 2-5-year-old } \\
\text { children with a TV in child's } \\
\text { bedroom. About } 33 \% \\
\text { identified as Black American } \\
\text { and } 51 \% \text { identified as } \\
\text { Latinx. }\end{array}$ & $\begin{array}{l}\text { Text messages } \\
\text { plus coaching calls } \\
\text { and home visits. }\end{array}$ & $\begin{array}{l}\text { Bilingual health educators used Ml techniques to } \\
\text { review progress and setbacks to behavior change, } \\
\text { discuss goals, and provide an activity or tool to } \\
\text { support behavior change. Monthly coaching calls } \\
\text { were designed to assess progress on making } \\
\text { changes, provide support for challenges, and } \\
\text { reinforce study messages. The intervention focused } \\
\text { on promotion of the key household behaviors with } \\
\text { particular attention to achieving the goals in } \\
\text { low-resource home environments. Text message } \\
\text { content focused on the adoption of household } \\
\text { routines discussed during coaching calls and home } \\
\text { visits. }\end{array}$ & $\begin{array}{l}\text { Duration: 6-months. } \\
\text { - Dose: Twice weekly } \\
\text { text messages for the } \\
\text { first } 16 \text { weeks and } \\
\text { weekly text } \\
\text { messages for last } \\
\text { 8-weeks; Monthly } \\
\text { coaching calls; Four } \\
\text { home visits. }\end{array}$ & $\begin{array}{l}\text { - Parents: Frequency of } \\
\text { meals where at least } \\
\text { some family members } \\
\text { ate together in past } 7 \\
\text { days. } \\
\text { - Child: Sleep duration, } \\
\text { screen time, BMl. }\end{array}$ \\
\hline
\end{tabular}




\begin{tabular}{|c|c|c|c|c|c|c|}
\hline $\begin{array}{l}\text { Study (Author name, } \\
\text { year, and city/state, risk } \\
\text { of bias) }\end{array}$ & Sample size & $\begin{array}{l}\text { Characteristics of } \\
\text { population }\end{array}$ & $\begin{array}{l}\text { DHI } \\
\text { methodology }\end{array}$ & Brief description of DHI & Duration and Dose & $\begin{array}{l}\text { Behavioral and } \\
\text { weight status } \\
\text { measures }\end{array}$ \\
\hline $\begin{array}{l}\text { Newton et al., 2014, } \\
\text { Louisiana, USA, high risk of } \\
\text { bias (54) }\end{array}$ & $N=27$ dyads & $\begin{array}{l}\text { 6-10-year-old children and } \\
\text { one of their } \\
\text { parents/guardians. About } \\
59 \% \text { identified as Black } \\
\text { American. }\end{array}$ & $\begin{array}{l}\text { Website and text } \\
\text { messages. }\end{array}$ & $\begin{array}{l}\text { Parent/guardian website provided access to view } \\
\text { their child's daily step goal, monitor their child's step } \\
\text { counts, view a color-coded steps/day graph to see } \\
\text { how their child's daily steps compared to target step } \\
\text { goal, and read weekly behavioral articles. } \\
\text { Text messages were designed to help } \\
\text { parents/guardians encourage their child's physical } \\
\text { activity, remind parents/guardians of behavioral } \\
\text { concepts presented in the website articles, and } \\
\text { motivate parents/guardians to support their child's } \\
\text { behavior change. }\end{array}$ & $\begin{array}{l}\text { Duration: } 12 \text { weeks. } \\
\text { Dose: Website updated } \\
\text { weekly; about seven } \\
\text { text messages/week in } \\
\text { minimal intervention } \\
\text { group; about } 13 \text { text } \\
\text { messages/week in } \\
\text { intensive } \\
\text { intervention group. }\end{array}$ & $\begin{array}{l}\text { - Parent/Guardian: } \\
\text { Home and } \\
\text { Neighborhood } \\
\text { Food Environment } \\
\text { Questionnaire (FFQ). } \\
\text { - Child: Sedentary } \\
\text { behavior, FFQ, } \\
\text { pedometer, BMI, } \\
\text { waist circumference, } \\
\text { body fat percentage, } \\
\text { fat free mass. }\end{array}$ \\
\hline $\begin{array}{l}\text { Nezami et al., 2018, Chapel } \\
\text { Hill, NC, USA, low risk of } \\
\text { bias (55) }\end{array}$ & $N=51$ dyads & $\begin{array}{l}\text { Parent/guardians (mothers) } \\
\text { with overweight or obesity, } \\
\text { who had a } 2-5 \text {-year-old } \\
\text { child that consumed } \geq 12 \\
\text { fluid oz./day of sugar } \\
\text { sweetened beverages } \\
\text { (SSB). About } 44 \% \text { identified } \\
\text { as Black American. }\end{array}$ & $\begin{array}{l}\text { Website, text } \\
\text { messages, e-mail. }\end{array}$ & $\begin{array}{l}\text { The goal of the intervention was to slowly reduce } \\
\text { the child's SSB/juice consumption until the child } \\
\text { was consuming } 1 \text { serving per day (1 child } \\
\text { serving = 4fl. oz.). } \\
\text { Parent/guardians self-monitored their weight, } \\
\text { number of servings of caloric beverages, and the } \\
\text { child's servings of SSB/juice in a paper or } \\
\text { smartphone diary. Parent/guardians received a text } \\
\text { message prompt each week to submit their diaries, } \\
\text { which were used to create personalized feedback. } \\
\text { Feedback was delivered via email and was tailored } \\
\text { to whether specific goals had been met. } \\
\text { Parents/guardians completed monthly brief } \\
\text { questionnaires in which they selected their greatest } \\
\text { barrier to meeting their goals. Reported barriers } \\
\text { were used to provide additional personalized } \\
\text { feedback in subsequent feedback email. } \\
\text { Parents/guardians accessed lessons on a mobile } \\
\text { website. The lessons focused on behavioral } \\
\text { strategies to achieve goals, including } \\
\text { parent/guardian-child communication, problem } \\
\text { solving, skills targeted to maternal weight loss such } \\
\text { as reading food labels and relapse prevention } \\
\text { strategies. } \\
\text { Text messages included link to lessons, tips, } \\
\text { motivational messages, and goal progress } \\
\text { assessments with a semi-automated tailored } \\
\text { feedback message based on responses. }\end{array}$ & $\begin{array}{l}\text { Duration: } 6 \text { months. } \\
\text { Dose: One 75-min } \\
\text { in-person group } \\
\text { session; Website } \\
\text { content updated } \\
\text { weekly during weeks } \\
2-12 \text { and biweekly } \\
\text { during weeks 13-24; } \\
\text { 3-4 text } \\
\text { messages/week; } \\
\text { Weekly emails on } \\
\text { self-monitoring for first } \\
\text { 12-weeks then } \\
\text { bi-weekly emails for } \\
\text { next 12-weeks. }\end{array}$ & $\begin{array}{l}\text { - Parent/Guardian: 24- } \\
\text { h dietary recall, BMI. } \\
\text { - Child: } 24-h \\
\text { dietary recall. }\end{array}$ \\
\hline
\end{tabular}




\begin{tabular}{|c|c|c|c|c|c|c|}
\hline $\begin{array}{l}\text { Study (Author name, } \\
\text { year, and city/state, risk } \\
\text { of bias) }\end{array}$ & Sample size & $\begin{array}{l}\text { Characteristics of } \\
\text { population }\end{array}$ & $\begin{array}{l}\text { DHI } \\
\text { methodology }\end{array}$ & Brief description of DHI & Duration and Dose & $\begin{array}{l}\text { Behavioral and } \\
\text { weight status } \\
\text { measures }\end{array}$ \\
\hline $\begin{array}{l}\text { Robinson et al., 2010, } \\
\text { Oakland, CA, USA, low risk } \\
\text { of bias (56) }\end{array}$ & $N=261$ & $\begin{array}{l}\text { 8-10-year-old Black } \\
\text { American girls and their } \\
\text { parents/guardians. }\end{array}$ & $\begin{array}{l}\text { Videotaped } \\
\text { feedback and TV } \\
\text { allowance } \\
\text { electronic time } \\
\text { manager. }\end{array}$ & $\begin{array}{l}\text { The after-school dance intervention included dance } \\
\text { performances every } 8 \text { weeks for families and } \\
\text { friends; videotaped feedback; opportunities for girls } \\
\text { to teach each other and choreograph routines; } \\
\text { opportunities for participant choice and control; and } \\
\text { performances at public events. } \\
\text { Sisters Taking Action to Reduce Television (START) } \\
\text { was a home-based screen time reduction } \\
\text { intervention designed to incorporate African or } \\
\text { Black American history and culture to reduce screen } \\
\text { time. Young Black American female mentors met } \\
\text { with families in their homes to deliver each lesson. }\end{array}$ & $\begin{array}{l}\text { Duration: After school } \\
\text { dance intervention was } \\
\text { 9-months; START was } \\
\text { conducted over } \\
\text { 2-years. } \\
\text { Dose: After school } \\
\text { dance intervention } \\
\text { offered } 5 \text { days/week for } \\
2.5 \text { h; START 12-24 } \\
\text { lessons over 2-years. }\end{array}$ & $\begin{array}{l}\text { - Parents/Guardians: } \\
\text { Black American } \\
\text { cultural identity. } \\
\text { - Child: Accelerometer, } \\
\text { screen time, meals } \\
\text { eaten with television } \\
\text { on, 24-h } \\
\text { dietary recall. }\end{array}$ \\
\hline $\begin{array}{l}\text { Taveras et al., 2017, } \\
\text { Massachusetts, USA, low } \\
\text { risk of bias (57) }\end{array}$ & $N=721$ & $\begin{array}{l}\text { 2-12-year-old children with } \\
\text { a BMI } \geq 85 \text { th percentile from } \\
\text { six primary care practices; } \\
\text { about } 33 \% \text { identified as } \\
\text { Black American and } 21.8 \% \\
\text { as Latinx. }\end{array}$ & $\begin{array}{l}\text { Text messages, } \\
\text { email, video calls, } \\
\text { and online } \\
\text { community } \\
\text { resource map. }\end{array}$ & $\begin{array}{l}\text { Clinicians received a computerized, clinical decision } \\
\text { support (CDS) alert during primary care visits } \\
\text { identifying children with a BMI } \geq 85 \text { th percentile. } \\
\text { They also received additional CDS tools to assist in } \\
\text { overweight and obesity management of children. } \\
\text { Clinicians provided parents/guardians with a set of } \\
\text { educational materials to support behavior change. } \\
\text { The materials focused decreasing screen time and } \\
\text { SSBs; improving diet quality; increasing moderate } \\
\text { and vigorous physical activity; and improving sleep } \\
\text { duration and quality. } \\
\text { In the enhanced primary care + coaching arm, } \\
\text { parents/guardians received individualized coaching } \\
\text { tailored to their socio-environmental context from } \\
\text { health coaches who used Ml techniques. Health } \\
\text { coaches contacted parents/guardians by phone, } \\
\text { videoconference, or in-person visits, according to } \\
\text { parent/guardian preference. Parents/guardians } \\
\text { received text messages or emails, following each } \\
\text { coaching session with educational materials to } \\
\text { support behavior change goals. At each contact, } \\
\text { health coaches used an online community resource } \\
\text { map to identify resources within each } \\
\text { parent/guardian's community that could support } \\
\text { behavior change. } \\
\text { Parents/guardians also received a 1-month free } \\
\text { YMCA membership and were invited to attend a } \\
\text { healthy grocery shopping program. }\end{array}$ & $\begin{array}{l}\text { Duration: } 1 \text { year. } \\
\text { Dose: Video calls every } \\
\text { other month; Twice } \\
\text { weekly text messages } \\
\text { or emails. }\end{array}$ & $\begin{array}{l}\text { - Parent/Guardian: } \\
\text { Parent Resource } \\
\text { Empowerment Scale. } \\
\text { - Child: BMI. }\end{array}$ \\
\hline
\end{tabular}




\begin{tabular}{|c|c|c|c|c|c|c|}
\hline $\begin{array}{l}\text { Study (Author name, } \\
\text { year, and city/state, risk } \\
\text { of bias) }\end{array}$ & Sample size & $\begin{array}{l}\text { Characteristics of } \\
\text { population }\end{array}$ & $\begin{array}{l}\text { DHI } \\
\text { methodology }\end{array}$ & Brief description of DHI & Duration and Dose & $\begin{array}{l}\text { Behavioral and } \\
\text { weight status } \\
\text { measures }\end{array}$ \\
\hline $\begin{array}{l}\text { Trude et al., 2019, } \\
\text { Baltimore, MD, USA, low } \\
\text { risk of bias (58) }\end{array}$ & $N=533$ & $\begin{array}{l}\text { Families with 9-15-year-old } \\
\text { children residing in } \\
\text { low-income, predominantly } \\
\text { Black American } \\
\text { neighborhoods with low } \\
\text { access to healthy foods. }\end{array}$ & $\begin{array}{l}\text { Text messages } \\
\text { and social media. }\end{array}$ & $\begin{array}{l}\text { The intervention used an ecological and food } \\
\text { systems approach. Individual-level components } \\
\text { were based in community recreation centers, using } \\
\text { youth leaders to provide education and nutrition } \\
\text { skills to youth. The family-level included social } \\
\text { media and text messages to target family-level } \\
\text { nutrition behaviors. Recipes, news, and } \\
\text { intervention-specific activities were featured in social } \\
\text { media and text messages. Text messages and } \\
\text { social media platforms provided parents/guardians } \\
\text { with guidance to set and achieve dietary goals for } \\
\text { themselves and their families, as well as promoting } \\
\text { intervention community activities. } \\
\text { The intervention promoted healthy foods/beverages } \\
\text { and behaviors in three sequential phases, each } \\
\text { lasting two months: (1) healthier beverages, (2) } \\
\text { healthier snacks, and (3) healthier cooking methods. }\end{array}$ & $\begin{array}{l}\text { Duration: } 6 \text { months. } \\
\text { Dose: Text messages } \\
\text { sent three times/week. }\end{array}$ & $\begin{array}{l}\text { - Parent/Guardian: } \\
\text { Fruit and vegetable } \\
\text { intake, household } \\
\text { food preparation, } \\
\text { frequency of food } \\
\text { acquisition. }\end{array}$ \\
\hline $\begin{array}{l}\text { White et al., } 2004 \text {, } \\
\text { Louisiana, USA, unclear risk } \\
\text { of bais (59) }\end{array}$ & $N=57$ & $\begin{array}{l}\text { 11-15-year-old Black } \\
\text { American girls who were } \\
\text { overweight and had a } \\
\text { parent/guardian with obesity } \\
(\mathrm{BMl}>30) \text {. }\end{array}$ & Website and email. & $\begin{array}{l}\text { Participants were provided with a home computer } \\
\text { and free internet access. Participants visited } \\
\text { website weekly and accessed material which } \\
\text { focused on weight loss, and included information on } \\
\text { nutrition, physical activity, and healthy food choices. } \\
\text { Behavior change strategies were highlighted in } \\
\text { weekly emails sent by a weight management case } \\
\text { manager. Topics included: self-monitoring, goal } \\
\text { setting, problem solving, behavioral contracting, and } \\
\text { relapse prevention. } \\
\text { Participants completed daily food records and } \\
\text { submitted them on the website. Food records were } \\
\text { reviewed by a dietician. Automated feedback was } \\
\text { also provided. A computer program generated an } \\
\text { image of the Food Guide Pyramid and indicated the } \\
\text { extent to which the food records complied with the } \\
\text { recommended nutritional values. }\end{array}$ & $\begin{array}{l}\text { Duration: 2-years } \\
\text { (6-month outcomes } \\
\text { reported). } \\
\text { Dose: Website content } \\
\text { updated, and emails } \\
\text { sent weekly. }\end{array}$ & $\begin{array}{l}\text { - Parent/Guardian: } \\
\text { Body fat (DEXA), BMI. } \\
\text { - Child: Body fat } \\
\text { (DEXA), BMl, dietary } \\
\text { self-efficacy, 24-h } \\
\text { dietary recall, } \\
\text { and FFQ. }\end{array}$ \\
\hline
\end{tabular}


TABLE 1 | Continued

\section{Study (Author name,}

Characteristics of

DHI

Brief description of DHI

Duration and Dose

Behavioral and

year, and city/state, risk

population

methodology

9-12-year-old children with obesity and their

parents/guardians attending

an urban pediatric

outpatient clinic. The

majority of participants

(72\%) identified as Black

American.

(60)

Interactive voice technology (IVR).

The IVR monitored, educated, and counseled parents/guardians and children on healthy weight

management and screen time. The IVR spoke using

Dose: Two calls

text-to-speech technology. Participants

communicated by speaking or by pressing keys on

telephone keypad. The IVR conversation was

tailored to each participant; it asked questions and provided tailored feedback.

Child intervention: Concepts from the Traffic Light Diet (TLD) and the Student Media Awareness to Reduce Television program guided the child IVR

conversations (e.g., increase consumption of green foods, reduce TV time to $<2 \mathrm{~h} /$ day). Conversation objectives included: (1) learn the TLD; (2) learn about rules; (3) self-monitor diet and screen time behaviors; and (4) set up contracts and rewards. Parent/Guardian intervention: IVR conversation content mirror children's conversation to encourage support and teamwork. Conversation objectives: (1) create a healthy home; (2) role modeling; (3) developing respectful parent/guardian-child relationship; (4) using praise and encouragement to motivate children; (5) follow the TLD with child to support efforts.

Children and parents/guardians were provided a guidebook to support the calls.

Data captured in the child IVR system were sent to

child's pediatrician via electronic health record.

Recommendations for praising, encouraging and

problem solving behaviors were provided

to pediatrician. 
basis during the second half of the DHI (55), and one study sent either text messages or e-mails twice weekly, depending on the parent's/caregiver's preference (57). All the studies that used email as part of their DHI strategy did so in combination with other DHI strategies.

Other DHI strategies utilized include Interactive Voice Technology (IVR) calls that occurred twice weekly (60), video stories updated weekly on a website (51), monthly coaching calls and home visits (53), video feedback provided at an after-school dance program offered 5 days/week and a TV time manager provided to families (56), an online community resource map provided to parents/caregivers after bi-monthly video calls (57), and social media (58).

\section{Parent/Caregiver Participation}

Parent/Caregiver participation measures and outcomes, and retention/loss to follow-up rates are reported in Table 2. Measurement of parent/caregiver participation in the DHIs included in this review varied. Two of the studies assessed text message response rate $(49,55)$ and four of the studies assessed the overall number of text messages sent $(49,54,57$, 58). Less than half of the studies $(n=5)$ assessed the average number of times parents/caregivers logged into the DHI website $(50-52,54,59)$ while half of the included studies $(n=6)$ assessed parent/caregiver satisfaction with the DHI $(49,51$, $53,55,57,60)$. Other parent/caregiver participation measures included feasibility of IVR calls (60), number of dance lessons attended and number of TV time managers connected (56), number of completed video calls (57), an Intervention Exposure Questionnaire (IEQ) (58), and the number of completed weekly quizzes and self-monitoring forms submitted (59).

Level of parent/caregiver participation varied. Overall, in studies that included text messaging response rate was high (above 80\%) and text message dose was close to as intended $(49,54,55,57,58)$. There was also moderate to high satisfaction with the DHI among parents/caregivers $(49,53,55,57)$. In studies with a website component, the mean website logon rate in two of the studies ranged from 47 to $86 \%$ over the 2 -month DHI period $(50,51)$ while one study reported that the mean number of times logged onto the website was 557 times over the 6-month DHI period (59). One study reported that the mean number of times parents/caregivers logged onto the website decreased over the duration of the 12-week DHI (54). Other parent/caregiver participation outcomes reported by studies with a website component were high satisfaction with the DHI (51), frequent logons to view their child's self-monitoring of behavior progress (54), and high completion rate of online modules (52).

In the IVR DHI, there was high satisfaction with IVR calls and $76 \%$ of parents/caregivers completed at least one IVR call (60). For those participating in the DHI with dance lessons plus videotaped feedback, $70 \%$ attended at least the first seven lessons and $77 \%$ of parents/caregivers connected their family TV to the time manager (56). Lastly, for the study with the social media component, overall social media exposure was low (mean social media exposure score: 0.2 (observed range: $0.0-2$ ), possible highest score: 2) (58). No parent/caregiver participation outcomes were reported for email strategies.

\section{Parent/Caregiver and Child Behavioral Outcomes}

Parent/Caregiver and child behavioral and weight status outcomes are also reported in Table 2. Of the studies included in this review, half $(n=6)$ reported non-significant outcomes for parents/caregivers and/or children in terms of behavioral and/or weight status outcomes for those in the intervention condition compared to the control $(49,50,52,54,56,57)$.

Four found significant positive changes in the dietary $(51,55$, $58,60)$ and weight status outcomes (55) of parents/caregivers in the intervention condition compared to those in the control. One of the included studies saw positive changes in the dietary outcomes of children in the intervention condition compared to children in the control condition (55), and two of the studies saw significant, positive changes in the weight status outcomes of children in the intervention condition when compared to the control $(53,59)$.

Of the studies with reported significant changes in the behavioral and/or weight status outcomes for parents/caregivers and/or children $(n=6)$, three reported high DHI utilization $(51,55,59,60)$ and three studies reported high satisfaction with the DHI $(51,53,55)$. One of the studies with reported significant changes in behavioral outcomes reported that each one-point increase in the DHI exposure score was associated with daily fruit intake, and despite the low exposure to the social media component, for each one-point increase in the social media exposure score, there was an increase in daily fruit intake and an increase in unhealthful food acquisition (58). Lastly, in studies with reported non-significant changes in the behavioral and/or weight status outcomes for parents/caregivers and/or children $(n=6)$, parent/caregiver participation ranged from low to high.

\section{DISCUSSION}

The primary aim of this systematic review was to identify Black American and/or Latinx parents'/caregivers' level of participation in DHIs for obesity prevention or treatment for their children. The secondary aim was to determine the relationship between parent/caregiver participation and behavioral, specifically diet and physical activity, and weight status outcomes for both parents/caregivers and children. Regarding parent/caregiver participation, across most DHI studies included, participation was relatively high, apart from a study that included a social media-based component; participation, as measured by an exposure score, for the social media-based component was low. However, this study did find that an increase in social media exposure score was associated with both positive and negative dietary behavior outcomes. These parent/caregiver participation findings offer promising support for the feasibility of DHIs for obesity prevention and treatment interventions in Black American and Latinx families with young children (52). However, only half $(n=6)$ of the included studies reported significant improvements in obesity or related health behaviors for parents/caregivers and/or their children. Of these 6 studies, three of them reported high parental/caregiver participation rates and 3 reported high satisfaction rates. These findings suggest 


\begin{tabular}{|c|c|c|c|c|c|}
\hline Study & $\begin{array}{l}\text { Parent/Caregiver } \\
\text { participation measures }\end{array}$ & Parent/Caregiver participation outcomes & $\begin{array}{l}\text { Retention/Loss to } \\
\text { follow-up/Withdrawal Rate }\end{array}$ & $\begin{array}{l}\text { Parent/Caregiver behavioral } \\
\text { and/or weight status } \\
\text { outcomes }\end{array}$ & $\begin{array}{l}\text { Child behavioral and/or } \\
\text { weight status } \\
\text { outcomes }\end{array}$ \\
\hline Armstrong et al. (49) & $\begin{array}{l}\text { - Text message response } \\
\text { rate. } \\
\text { - Acceptability of text } \\
\text { message frequency, } \\
\text { timing, and content. } \\
\text { - Perceived usefulness. } \\
\text { - Text message dose. }\end{array}$ & $\begin{array}{l}\text { Text message response rate: } \\
\text { - Parents/caregivers responded at least once to } 80 \% \text { of text } \\
\text { messages and parents/caregivers responded twice or more to } \\
30 \% \text { of text messages. } \\
\text { Acceptability: } \\
\text { - } 81 \% \text { of parents/caregivers enjoyed receiving messages; } 92 \% \\
\text { felt they were personalized; } 62 \% \text { wanted to receive texts past } \\
\text { the study period; and } 92 \% \text { would recommend to a friend. } \\
\text { Perceived usefulness: } \\
\text { - } 95 \% \text { of parents/caregivers perceived the frequency "just right," } \\
\text { and } 95 \% \text { said messages "almost always" or "always" helped } \\
\text { them make a good decision about their child's health. } \\
\text { Text message dose: } \\
\text { - Participants received a mean of } 60 \text { messages over the } \\
\text { study period. }\end{array}$ & - $81 \%$ retention rate & $\begin{array}{l}\text { - No significant differences } \\
\text { observed. }\end{array}$ & $\begin{array}{l}\text { - No significant } \\
\text { differences observed. }\end{array}$ \\
\hline Baranowski et al. (50) & Weekly log-on rates. & $\begin{array}{l}\text { Weekly log-on rate: } \\
\text { - Mean log-on rate for parents/caregivers was } 47 \% \text {. }\end{array}$ & - Reports camp attendance. & - Not applicable. & $\begin{array}{l}\text { - No significant } \\
\text { differences observed. }\end{array}$ \\
\hline Cullen et al. (51) & $\begin{array}{l}\text { Website log-on. Website } \\
\text { evaluation: } \\
\text { parents/caregivers asked to } \\
\text { grade the program. }\end{array}$ & $\begin{array}{l}\text { Website log-on: } \\
\text { - Website log-on rate over intervention period was } 86 \% \text {. } \\
\text { - } 66 \% \text { of parents/caregivers logged onto all } 8 \text { sessions. } \\
\text { Website evaluation: } \\
\text { - Parents/caregivers in both conditions reported liking the } \\
\text { program components; } 63 \text { parents/caregivers graded it an A } \\
\text { or B. }\end{array}$ & $\begin{array}{l}\text { - } 66 \% \text { of intervention families } \\
\text { and } 74 \% \text { of control families } \\
\text { completed all data collection } \\
\text { surveys. }\end{array}$ & $\begin{array}{l}\text { - Meat modification was } \\
\text { significantly higher at follow-up } \\
\text { for both intervention and } \\
\text { control parents/caregivers. } \\
\text { - The reduced-fat scale and the } \\
\text { substitutions scale was } \\
\text { significantly higher at } \\
\text { post-intervention and at } \\
\text { follow-up for intervention } \\
\text { parents/caregivers. } \\
\text { - The fruit and vegetables scale } \\
\text { was significantly higher at } \\
\text { post-intervention and follow-up } \\
\text { for intervention } \\
\text { parents/caregivers and at } \\
\text { follow-up for control } \\
\text { group parents/caregivers. }\end{array}$ & $\begin{array}{l}\text { - No significant } \\
\text { differences observed. }\end{array}$ \\
\hline Frenn et al. (52) & $\begin{array}{l}\text { Feasibility: Number of } \\
\text { returned completed consent } \\
\text { forms, and visits to } \\
\text { intervention components in } \\
\text { the online program. }\end{array}$ & $\begin{array}{l}\text { Feasibility } \\
\text { - Of the } 161 \text { parents/caregivers invited, no response was received } \\
\text { from } 98 . \\
\text { - Parents/caregivers of } 5 \text { th graders }=52 \% \text { response rate. } \\
\text { - Parents of } 7 \text { th- } 8 \text { th graders }=30 \% \text { response rate at public } \\
\text { school; } 36 \% \text { at private school. } \\
\text { - } 81 \% \text { of parents/caregivers and children completed pretest data. } \\
\text { - } 9 \text { parents/caregivers who agreed to complete the online } \\
\text { modules did not. }\end{array}$ & $\begin{array}{l}\text { - } 30 \% \text { retention for } \\
\text { parents/caregivers } \\
\text { - } 90 \% \text { for children }\end{array}$ & $\begin{array}{l}\text { - No significant differences } \\
\text { observed. }\end{array}$ & $\begin{array}{l}\text { - No significant } \\
\text { differences observed. }\end{array}$ \\
\hline
\end{tabular}


TABLE 2 | Continued

Parent/Caregiver

Retention/Loss to

Parent/Caregiver behavioral

participation measures

follow-up/Withdrawal Rat

and/or weight status

Child behavioral and/or

outcomes

Parent/caregiver satisfaction - $89 \%$ of parents/caregivers reported being "satisfied" or "very

- Intervention group $=6$ lost to - No significant differences

observed.

satisfied" with the program

$98 \%$ were "satisfied" or "very satisfied" with the counseling

follow-up.

during home visits.

Control group $=2$ lost

98\% were "satisfied" or "very satisfied" with the counseling

to follow-up.

received during coaching calls.

-98\% of parents reported they would recommend the program to friends and family.

Newton et al. (54)

- Website log-on rates and
views.
- Self-monitoring of step
counts.
- Text message
response frequency.

Nezami et al. (55)

- Program utilization.

- Program satisfaction.
- Website log-on rates and views:

- 38\% of parents/caregivers accessed 9 or more articles; $23 \%$

accessed between 4 and 8; 38\% accessed $<4$ articles; 2

parents never accessed an article.

Parents/caregivers accessed $70 \%$ of articles in Month $1 ; 60 \%$ in

Month 2; and 37.5\% in Month 3.

Self-monitoring of step counts:

Parents/caregivers visited the steps/day graph an average of

25.3 (SD 24.5) times over the course of the study

( 2.1 times/week).

Number of text messages sent:

Parents/caregivers in control group sent 162 (0.96/week) text messages.

- Parents/caregivers in intervention group sent 419 (2.7/week) text messages.

Program utilization:

Parents/caregivers submitted an average of 21.5 (4.3) out of 24 weeks of self-monitoring texts and responded to an average of 15.4 (1.7) out of 18 goal progress assessment texts.
- None lost to follow-up.

Retention rate: $86 \%$ at

3 -months and $82 \%$ at

6-months.
No significant differences observed.

Self-monitoring and goal progress assessment texts predicted greater weight loss: intervention group lost $2.4 \mathrm{~kg}$ which was significantly greater than the weight gain of $0.9 \mathrm{~kg}$ observed among contro

group.
Significant decrease in BMl by a mean of 0.18 in the intervention group and increased by 0.21 in the control group at 6mos.

Significant increase in sleep duration by 0.56 $\mathrm{h} /$ day in the intervention group and decreased by $0.19 \mathrm{~h} /$ day in the control group.

Significant, larger decreases in weekend $T V$ viewing were observed among intervention group compared with the control $(-1.06 \mathrm{~h} / \mathrm{d} ; 95 \%$ $\mathrm{Cl},-1.97$ to -0.15$)$.

- For pedometer step counts, children in both groups demonstrated significant increases in steps by 1427.6 (SD 583.0) for control and 2832.8 (SD 604.9) for intervention. The between-group and group by time difference was not statistically significant.

No other significant differences detected.

Significant difference observed for change in child SSB/juice intake at both 3 and 6 months; children in intervention group had a greater reduction compared with the control group at 3 months (-9.9fl. oz. day vs. $-2.7 f$. oz. day) and 6 months ( $-9.7 \mathrm{fl}$.

oz./day vs. $-1.7 \mathrm{fl}$.

oz./day). 
TABLE 2 | Continued

\begin{tabular}{|c|c|c|c|c|c|}
\hline Study & $\begin{array}{l}\text { Parent/Caregiver } \\
\text { participation measures }\end{array}$ & Parent/Caregiver participation outcomes & $\begin{array}{l}\text { Retention/Loss to } \\
\text { follow-up/Withdrawal Rate }\end{array}$ & $\begin{array}{l}\text { Parent/Caregiver behavioral } \\
\text { and/or weight status } \\
\text { outcomes }\end{array}$ & $\begin{array}{l}\text { Child behavioral and/or } \\
\text { weight status } \\
\text { outcomes }\end{array}$ \\
\hline & & $\begin{array}{l}\text { - Parents/caregivers reported spending } \sim 50 \mathrm{~min} / \text { week } \\
\text { completing study-related activities. } \\
\text { - Program satisfaction } \\
\text { - All intervention parents/caregivers reported that they would } \\
\text { "probably" or "definitely" recommend the program to a friend. } \\
\text { - } 91 \% \text { of parents/caregivers reported being satisfied with } \\
\text { the program. }\end{array}$ & & $\begin{array}{l}\text { - A greater proportion of } \\
\text { intervention parents/caregivers } \\
\text { (37\%) reached a weight loss of } \\
3 \% \text { compared to control ( } 4 \%) \text {, } \\
\text { and a greater proportion } \\
\text { reached a weight loss of } 5 \% \\
\text { compared to control (22 vs. } \\
\text { 0\%). } \\
\text { - Intervention parents/caregivers } \\
\text { had a greater reduction in } \\
\text { caloric beverages compared } \\
\text { with the control } \\
\text { parents/caregivers (-11.5fl. } \\
\text { oz./day vs. } 0.4 f l .0 z . / d a y) .\end{array}$ & $\begin{array}{l}\text { - Significant difference } \\
\text { observed for meeting } \\
\text { SSB goal, } 52 \% \text { of } \\
\text { children met the goal of } \\
\text { consuming }<4 \text { oz./day } \\
\text { of SSB/juice at } 6 \\
\text { months, compared with } \\
21 \% \text { in the } \\
\text { control group. }\end{array}$ \\
\hline Robinson et al. (56) & $\begin{array}{l}\text { - Number of START lessons } \\
\text { received. } \\
\text { - Use of TV Allowance } \\
\text { time manager. }\end{array}$ & $\begin{array}{l}\text { START lessons: } \\
\text { - Delivered mean of } 12.4 \text { out of } 25 \text { START lessons. } \\
\text { - } 70 \% \text { of families received at least the first } 7 \text { lessons, } 29 \% \\
\text { received } 7-14 \text { lessons, } 34 \% \text { received } 15-20 \text { lessons, and } 7 \% \\
\text { received } 21 \text { or more. } \\
\text { TV Allowance: } \\
\text { - } 77 \% \text { of families hooked up at least one TV allowance manager } \\
\text { ( } 12 \% \text { two or more). } \\
\text { - The mean reported weekly screen time budget goal was } 10.0 \\
\pm 2.4 \mathrm{~h} \text {. }\end{array}$ & $\begin{array}{l}-18 \text { girls were lost to follow-up; } \\
94 \% \text { of girls in the intervention } \\
\text { condition and } 92.1 \% \text { of girls in } \\
\text { the control condition } \\
\text { completed at least one } \\
\text { follow-up assessment. }\end{array}$ & $\begin{array}{l}\text { Treatment parents had } \\
\text { significantly increased } \\
\text { preference for Black American } \\
\text { things compared to control } \\
\text { parents. }\end{array}$ & $\begin{array}{l}\text { - No significant } \\
\text { differences observed. }\end{array}$ \\
\hline Taveras et al. (57) & $\begin{array}{l}\text { - Text messages: Percent } \\
\text { received and satisfaction. } \\
\text { - Neighborhood Resource } \\
\text { Guide: Percent received } \\
\text { and satisfaction. } \\
\text { - Percent completion of } \\
\text { health coach visits. } \\
\end{array}$ & $\begin{array}{l}\text { Text messages: } \\
\text { - In the enhanced primary care group, 91\% of parents/caregivers } \\
\text { reported they received text messages and 53\% were satisfied } \\
\text { with their content. } \\
\text { - In the enhanced primary care + coaching group, } 100 \% \text { of } \\
\text { parents/caregivers reported receiving the study text messages } \\
\text { and } 72 \% \text { were very satisfied with their content. } \\
\text { - Neighborhood Resource Guide } \\
\text { - In the enhanced primary care group, } 60 \% \text { of parents/caregivers } \\
\text { reported receiving the Neighborhood Resource Guide and } 66 \% \\
\text { reported being very satisfied with its content. } \\
\text { - In the enhanced primary care + coaching group } 96 \% \text { reported } \\
\text { receiving neighborhood resource information and } 76 \% \text { were } \\
\text { very satisfied with the information. } \\
\text { Health Coach Visits: } \\
\text { - In the enhanced primary care, } 65 \% \text { completed all } 6 \text { visits with a } \\
\text { health coach. }\end{array}$ & $\begin{array}{l}\text { Retention rate for } \\
\text { intervention group: } \\
\text { - 90\% for parents/caregivers } \\
\text { - 93\% for children. }\end{array}$ & $\begin{array}{l}\text { - No significant differences } \\
\text { observed. }\end{array}$ & $\begin{array}{l}\text { - No significant } \\
\text { differences observed. }\end{array}$ \\
\hline
\end{tabular}


- Parents/caregivers presented an overall exposure score of 1.38

Attrition rate $=24.9 \%$

- Not reported. Questionnaire: Self-reported points, SD \pm 1.2 (range: 0-6.9).

viewing of communication - The Communication Materials exposure score was 0.6 points.

materials, participation in - The Food Environment exposure score was 0.3 points.

food environment _ - The Social Media exposure score was 0.2 points.

intervention activities, - Text Messaging exposure score (based on the frequency of text enrollment in social media, messages received per week) was 1.10 points.

receipt of text messages.

White et al. (59)

Wright et al. (60)
Website log-on rates.

Weekly quiz completion.

Frequency counts of the number of food diaries

and exercise

self-monitoring

forms submitted.

Use, credibility, and

satisfaction.

- Feasibility.
Website log-on rates

Intervention group website visits: mean of 557.3 (SD 500.4)

- Control group website visits: mean of 226.8 (SD 161.8).

- Other parent participation outcomes not reported.

Use, credibility, and satisfaction:

- Of parents/caregivers who made $\geq 1$ call, $\geq 75 \%$ agreed it was useful, easy to use, made for people like them, credible, and

helped them eat healthy foods, and watch less TV.

- $100 \%$ of parents/caregivers would recommend it to a friend, and $100 \%$ agreed they liked it because they could use it at home.

Feasibility:

$-76 \%$ of parents/caregivers called the IVR at least once; of those who called at least once, the mean number of total calls was 9.1 $(\mathrm{SD}=5.2)$.

Parents/caregivers made an average of $5.2(\mathrm{SD}=2.8)$

education and behavior calls and $3.9(\mathrm{SD}=2.6)$ tracking calls. observed for food acquisition

home food preparation, and

daily consumption of $\mathrm{FV}$.

- For each one-point increase in

exposure score, there was a

0.24 increase in mean daily

fruit serving for

parents/caregivers in

intervention group $(0.24 \pm$

$0.11 ; 95 \% \mathrm{Cl} 0.04 ; 0.47)$

For each one-point increase in

the social media exposure

score, there was an increased

three servings of daily fruit

intake (3.16 $\pm 0.92 ; 95 \% \mathrm{Cl}$

$1.33 ; 4.99)$ and an increase in

daily fruit and vegetable intake

2.94 土 1.01; 95\% Cl 0.96;

4.93).

- Higher social media exposure

score was associated with

increased unhealthful food

acquisition score $(0.47 \pm 0.23$

$95 \% \mathrm{Cl} 0.02 ; 0.93$ )

Lost to follow-up: $17.8 \%$ in the No significant differences intervention group and $6.9 \%$ in detected.

Adolescents in the the control group.

behavioral group lost more fat than those in the control group $(F=3.44, p$ $<0.05, b=0.28, p<$

$0.05)$
Lost to follow-up: $12.5 \%$ in the intervention group and $15.4 \%$ in

the control group.

t.

Intervention parents/caregivers No significant differences consumed 1.1 more cups of observed.

fruit per day than control

$\left[F_{(1,40)}=4.22, p=0.046\right)$; but intervention parents/caregivers consumed fewer servings of

vegetables than control parents/caregivers

$\left[F_{(1,40)}=6.88, p=0.012\right]$. - Analyses of high vs. low users of IVR found that the high users consumed significantly fewer calories compared to the low users. 
TABLE 3 | Recommendations for future DHI research.

\begin{tabular}{|c|c|}
\hline DHI study component or consideration & Proposed recommendation \\
\hline Parent/caregiver participation measurement & $\begin{array}{l}\text { - If utilizing multiple DHI strategies or features, collect data on participation from each of the DHI features. } \\
\text { - Collect data on participation from each of the DHI behavior change strategies utilized. } \\
\text { - Track and evaluate participation throughout DHI study to identify optimal dose and intensity. } \\
\text { - Utilize participation measures from previous studies so that participation can be compared across DHI studies. } \\
\text { - Collect qualitative data to better understand experiences with the DHI. }\end{array}$ \\
\hline Parent/caregiver reach and participation & $\begin{array}{l}\text { - Report recruitment rates and strategies for researchers to replicate. } \\
\text { - Collect contextual data to understand how best to reach and engage Black American and Latinx parents in DHI (e.g., } \\
\text { ambient or mobile device sensors, qualitative data, observational data, ecological momentary assessments, contextual } \\
\text { assessments of various settings where DHI may be used by parents/caregivers). } \\
\text { - Subgroup analyses to determine if race/ethnicity is a moderating factor in treatment effects or participation. }\end{array}$ \\
\hline Team science-based approaches & $\begin{array}{l}\text { - Development of transdisciplinary teams (e.g., experts from public health, computer science, artificial intelligence, } \\
\text { behavioral science, nutrition, kinesiology, policy, among others), in addition to academic-community and } \\
\text { academic-industry partnerships, to best synthesize, apply, and extend discipline-specific theories, concepts, and/or } \\
\text { methods to better develop and implement DHls for obesity prevention and treatment. }\end{array}$ \\
\hline
\end{tabular}

that participation and satisfaction may have an impact on health behavior change and weight status, but the small number of studies suggests that additional research needs to be conducted to determine whether these engagement factors or other factors predict responsiveness to the DHI.

\section{Implications and Recommendations for Future Research}

Given the range of DHI strategies used and the varied measures of parent/caregiver participation utilized within the studies, it is difficult to compare the studies in terms of parent/caregiver participation and how their participation may vary by DHI strategy or how their participation may influence behavioral and health outcomes. More consistent measurement of participation outcomes is needed across DHI studies and researchers need to adequately plan for and collect participation data so that we can better understand the relationship between parent/caregiver participation, DHI strategies, and behavioral and health outcomes. Due to technological advancements, it is now possible to collect data on both participation with a DHI's features, as well as participation in specific behavior change DHI strategies (62). Given this, there is an opportunity for researchers to track and assess participation for their duration of their study and to collect DHI participation data similarly to how others are, which would make comparisons across studies more feasible. Having such information would assist in identifying the optimal dose and intensity of DHI intervention activities to achieve desired behavioral and health outcomes (58). Additionally, such data would allow researchers to follow the advancements in DHI research over time, and provide researchers the opportunity to assess the benefits and limitations of various types of behavioral-based DHI strategies in terms of impact and outcomes (34). Lastly, it would also be useful for researchers to collect qualitative data from parents/caregivers and other stakeholders (e.g., think-aloud interviews, key informant interviews) to better understand and explain experiences with the DHI (63). Such approaches are consistent with community engagement and human-centered design approaches, which aims to design interventions with the user in mind, which is particularly important in health equity research $(64,65)$.
Other efforts need to focus on increasing our understanding of how best to reach Black American and Latinx families to enroll in DHI research and how best to maintain their engagement in the DHI. One way to increase our understanding of this is to understand how participation in a DHI may be affected by contextual factors $(66,67)$. DHIs are typically delivered in real-world settings, where everyday health behavior change may or may not occur (68). This means that DHI participation may be positively or negatively affected by contextual influences such as family, school, work, or broader community and societal influences (69). DHI participation may also be affected by parent's/caregiver's ability to access internet services. Black Americans and Latinx adults are almost twice as likely as nonLatinx white adults to have canceled internet services because of the expense and are more likely to access internet services in community venues such as libraries (33). Contextual data can be collected in a multitude of ways. For example, ambient or mobile device sensors to capture data such as location, weather, or busyness of day based on calendar, structured or semistructured interviews, observational data, ecological momentary assessments, or contextual assessments of various settings (e.g., home, neighborhood, food environments) (69-71). None of the studies included in this review reported on contextual factors. Such data would allow researchers to better understand how contextual factors may impact one's participation in a DHI so that the DHI can be delivered at times parents/caregivers are more likely to engage with the DHI (e.g., text messages sent at specific times of day or days of the week), or more likely to engage in the desired behavior, or so that it can incorporate features that may address contextual factors to further support behavior change. Strategies such as this are commonly used in digital justin-time adaptive interventions that target individuals at suitable moments, particularly when they have the opportunity to engage in a healthy behavior and are more receptive to support offered by the DHI (72). But to target individuals at these opportune moments, contextual data is required.

DHIs are just one strategy to advance healthy eating and physical activity and support diverse parents in modeling healthful behavior. As technology advances these types of interventions will become more powerful. However, dietary 
and physical activity behaviors are complex and are influenced by multifactorial determinants beyond the individual-level (73). Not one specific type of individual-level intervention can stem the tide of obesity inequities until we address and target multilevel determinants from the individual-, the family-, the environmental-, and the policy-levels (74). Multilevel interventions are one potential solution to address this but are often costly. Team science is an emerging area of exploratory and intervention public health research that promotes interdisciplinary and transdisciplinary collaboration to address public health phenomena (75). Multifactorial causes of public health phenomena such as obesity inequities requires greater collaboration among scientists trained in different fields (76-78). With a team science and transdisciplinary approach, researchers can work jointly to synthesize, apply, and extend their discipline-specific theories, concepts, and/or methods to better incite discovery and inform solutions to reduce obesity inequities (74). Therefore, it is recommended that team science approaches and partnerships are utilized to address the obesity inequities faced by Black American and Latinx families. This can include transdisciplinary partnerships (e.g., experts from public health, psychology, computer science, policy, nutrition, kinesiology, among others) in addition to academic-industry partnerships or academic-community partnerships. Our recommendations for future research are summarized in Table 3.

\section{Strengths and Limitations}

Our study should be considered within the context of several limitations. First, only 12 studies met our inclusion criteria limiting the amount of data available to make meaningful conclusions. Second, given our focus on a processrelated outcome, parent/caregiver participation, which does not influence how the primary outcomes were assessed, we did not assess studies for quality or bias. This limits our ability to conduct a formal assessment of the quality of evidence provided (79). Third, although we conclude that parent/caregiver participation was moderate to high across most of the studies, not all studies reported on recruitment rates. Previous research has found that recruiting Black American and Latinx participants in research studies is a challenge $(80,81)$ and although we were able to capture studies that successfully recruited samples that were at least 25\% Black American and Latinx, these participants may have been highly motivated to engage given that they participated in the studies. Future research should determine predictors of and barriers to enrolling in DHIs for obesity prevention and treatment within these populations to increase enrollment in future studies. Further, there are some limitations of the literature overall that are noteworthy. First, the variation in types of digital interventions and intervention components complicates the broad conclusions we can make about which intervention components are the best in terms of maintaining participation and changing diet and physical activity behaviors. Related, the time of intervention and dose of the intervention varied across studies so it is difficult to determine with certainty which components and how intense the intervention should be to result in meaningful change.

This is the first systematic review of Black American and Latinx parent/caregiver participation in obesity prevention and treatment DHIs for their children. This review is an important step in increasing our understanding of engaging two populations that are systematically and disproportionately affected by overweight and obesity in the United States. Additionally, this review focused on randomized controlled trials, which are considered the gold standard study design. Lastly, a team of reviewers were involved during the selection and data extraction process which minimized the potential for selection bias.

\section{CONCLUSIONS}

Given these limitations, future research should clearly define recruitment rates and recruitment strategies so that other researchers can replicate methods that are successful. Additionally, it is important to determine which treatment components and what intensity is necessary for meaningful changes. Further, it is important to test longitudinal changes in health behaviors and obesity-related outcomes from DHIs to determine whether the changes sustain over time. Finally, future research should determine predictors of responsiveness to the intervention (e.g., parent/caregiver participation, satisfaction, etc.) and, if a study includes more than one race/ethnicity within its sample, subgroup analyses should be conducted to determine if DHI treatment effects or participation are moderated by race/ethnicity.

Overall, our study represents an important first step to determining parent/caregiver participation and behavior change outcomes for DHIs in two populations systematically and disproportionately impacted by obesity; Black American and Latinx families. Our results lay the groundwork for the developing and testing of future DHI interventions with the explicit goal of increasing Black American and Latinx parental/caregiver participation and considers the need to expand our DHI research methodologies to better address obesity inequities among diverse families.

\section{DATA AVAILABILITY STATEMENT}

The original contributions presented in the study are included in the article/Supplementary Material, further inquiries can be directed to the corresponding author/s.

\section{AUTHOR CONTRIBUTIONS}

JS-F and MF conceptualized and designed the study. JS-F, AO'D, $\mathrm{MC}$, and JB conducted the screening of titles, abstracts, and fulltext articles and extracted the data of each study. All authors contributed to the drafting of the manuscript and approved of the final version.

\section{FUNDING}

This study was funded by the NCI Training Program: Cancer Education \& Career Development Program (T32CA057699) and the University of Illinois Cancer Center. 


\section{ACKNOWLEDGMENTS}

The authors would like to acknowledge Rosie Hanneke, MLS, for assisting with the development and execution of the search strategy.

\section{REFERENCES}

1. Robinson WR, Keyes KM, Utz RL, Martin CL, Yang Y. Birth cohort effects among US-born adults born in the 1980s: foreshadowing future trends in US obesity prevalence. Int J Obes. (2013) 37:448-54. doi: 10.1038/ijo.2012.66

2. Kotsis V, Stabouli S, Bouldin M, Low A, Toumanidis S, Zakopoulos N. Impact of obesity on 24-hour ambulatory blood pressure and hypertension. Hypertension. (2005) 45:602-7. doi: 10.1161/01.HYP.0000158261.86674.8e

3. Abdullah A, Peeters A, De Courten M, Stoelwinder J. The magnitude of association between overweight and obesity and the risk of diabetes: a metaanalysis of prospective cohort studies. Diabetes Res Clin Pract. (2010) 89:30919. doi: 10.1016/j.diabres.2010.04.012

4. Todd Miller M, Lavie CJ, White CJ. Impact of obesity on the pathogenesis and prognosis of coronary heart disease. J Cardiometab Syndr. (2008) 3:162-7. doi: 10.1111/j.1559-4572.2008.00004.x

5. Mitchell AB, Cole JW, McArdle PF, Cheng YC, Ryan KA, Sparks MJ, et al. Obesity increases risk of ischemic stroke in young adults. Stroke. (2015) 46:1690-2. doi: 10.1161/STROKEAHA.115.008940

6. Reyes C, Leyland KM, Peat G, Cooper C, Arden NK, Prieto-Alhambra D. Association between overweight and obesity and risk of clinically diagnosed knee, hip, and hand osteoarthritis a population-based cohort study. Arthritis Rheumatol. (2016) 68:1869-75. doi: 10.1002/art.39707

7. Berger NA. Young adult cancer: influence of the obesity pandemic. Obesity. (2018) 26:641-50. doi: 10.1002/oby.22137

8. Liu PH, Wu K, Ng K, Zauber AG, Nguyen LH, Song M, et al. Association of obesity with risk of early-onset colorectal cancer among women. JAMA Oncol. (2019) 5:37-44. doi: 10.1001/jamaoncol.2018.4280

9. Hales CM, Fryar CD, Carroll MD, Freedman DS, Ogden CL. Trends in obesity and severe obesity prevalence in US youth and adults by sex and age, 2007-2008 to 2015-2016trends in obesity prevalence in US youth and adults, 2007-2008 to 2015-2016 Letters. JAMA. (2018) 319:1723-5. doi: 10.1001/jama.2018.3060

10. Ogden CL, Carroll MD, Fryar CD, Flegal KM. Prevalence of Obesity Among Adults and Youth: United States, 2011-2014. Hyattsville, MD: NCHS Data Brief (2015)

11. Baker JL, Olsen LW, Sørensen TIA. Childhood body-mass index and the risk of coronary heart disease in adulthood. N Engl J Med. (2007) 357:2329-37. doi: 10.1056/NEJMoa072515

12. Sung H, Siegel RL, Rosenberg PS, Jemal A. Emerging cancer trends among young adults in the USA: analysis of a population-based cancer registry. Lancet Public Heal. (2019) 4:e137-47. doi: 10.1016/S2468-2667(18)30267-6

13. Rehm C, Peñalvo J, Afshin A, Mozaffarian D. Dietary intake among US adults, 1999-2012. JAMA. (2016) 315:2542-53. doi: 10.1001/jama.2016.7491

14. Beets MW, Bornstein D, Dowda M, Pate RR. Compliance with national guidelines for physical activity in U.S. preschoolers: measurement and interpretation. Pediatrics. (2011) 127:658-64. doi: 10.1542/peds.2010-2021

15. Reedy J, Krebs-Smith SM. Dietary sources of energy, solid fats, and added sugars among children and adolescents in the United States. J Am Diet Assoc. (2010) 110:1477-84. doi: 10.1016/j.jada.2010.07.010

16. Piernas C, Popkin BM. Increased portion sizes from energy-dense foods affect total energy intake at eating occasions in US children and adolescents: patterns and trends by age group and sociodemographic characteristics, 1977-2006. Am J Clin Nutr. (2011) 94:1324-32. doi: 10.3945/ajcn.110. 008466

17. Robson SM, Khoury JC, Kalkwarf HJ, Copeland K. Dietary intake of children attending full-time child care: what are they eating away from the childcare center? J Acad Nutr Diet. (2015) 115:1472-8. doi: 10.1016/j.jand.2015. 02.029

\section{SUPPLEMENTARY MATERIAL}

The Supplementary Material for this article can be found online at: https://www.frontiersin.org/articles/10.3389/fdgth. 2021.687648/full\#supplementary-material

18. Sisson SB, Kiger AC, Anundson KC, Rasbold AH, Krampe M, Campbell $\mathrm{J}$, et al. Differences in preschool-age children's dietary intake between meals consumed at childcare and at home. Prev Med Rep. (2017) 6:33-7. doi: 10.1016/j.pmedr.2017.02.003

19. Guerrero AD, Chung PJ. Racial and ethnic disparities in dietary intake among california children. J Acad Nutr Diet. (2016) 116:439-48. doi: 10.1016/j.jand.2015.08.019

20. Trost SG, Mccoy TA, Vander Veur SS, Mallya G, Duffy ML, Foster GD. Physical activity patterns of inner-city elementary schoolchildren. Med Sci Sports Exerc. (2013) 45:470-4. doi: 10.1249/MSS.0b013e318275e40b

21. Dev DA, McBride BA, Fiese BH, Jones BL, Cho H, and Behalf of The Strong Kids Research Team. Risk factors for overweight/obesity in preschool children: an ecological approach. Child Obes. (2013) 9:399-408. doi: 10.1089/chi.2012.0150

22. Nezami BT, Lytle LA, Tate DF. A randomized trial to reduce sugarsweetened beverage and juice intake in preschool-aged children: description of the Smart Moms intervention trial. BMC Public Health. (2016) 16:837. doi: 10.1186/s12889-016-3533-8

23. Birch LL, Davison KK. Childhood and adolescent obesity family environmental factors influencing the developing behavioral controls of food intake and childhood overweight all in the family: mediators of family resemblances in eating and weight. Pediatr Clin North Am. (2001) 48:893-905. doi: 10.1093/tbm/ibz050

24. Loprinzi PD, Trost SG. Parental influences on physical activity behavior in preschool children. Prev Med. (2010) 50:129-33. doi: 10.1016/j.ypmed.2009.11.010

25. Ash T, Agaronov A, Young T, Aftosmes-Tobio A, Davison KK. Familybased childhood obesity prevention interventions: a systematic review and quantitative content analysis. Int J Behav Nutr Phys Act. (2017) 14:113. doi: 10.1186/s12966-017-0571-2

26. Sisson SB, Krampe M, Anundson K, Castle S. Obesity prevention and obesogenic behavior interventions in child care: a systematic review. Prev Med. (2016) 87:57-69. doi: 10.1016/j.ypmed.2016.02.016

27. Ward DS, Welker E, Choate A, Henderson KE, Lott M, Tovar A, et al. Strength of obesity prevention interventions in early care and education settings: a systematic review. Prev Med. (2017) 95:S37-52. doi: 10.1016/j.ypmed.2016.09.033

28. Stark LJ, Spear S, Boles R, Kuhl E, Ratcliff M, Scharf C, et al. A pilot randomized controlled trial of a clinic and home-based behavioral intervention to decrease obesity in preschoolers. Obesity. (2011) 19:134-41. doi: 10.1038/oby.2010.87

29. O’Dwyer MV, Fairclough SJ, Knowles Z, Stratton G. Effect of a family focused active play intervention on sedentary time and physical activity in preschool children. Int J Behav Nutr Phys Act. (2012) 9:117. doi: 10.1186/1479-5868-9-117

30. Østbye T, Krause KM, Stroo M, Lovelady CA, Evenson KR, Peterson $\mathrm{BL}$, et al. Parent-focused change to prevent obesity in preschoolers: results from the KAN-DO study. Prev Med. (2012) 55:188-95. doi: 10.1016/j.ypmed.2012.06.005

31. Fitzgibbon ML, Stolley MR, Schiffer L, Kong A, Braunschweig CL, GomezPerez SL, et al. Family-based hip-hop to health: outcome results. Obesity. (2013) 21:274-83. doi: 10.1002/oby.20269

32. Pew Research Center. Demographics of Mobile Device Ownership and Adoption in the United States | Pew Research Center. Washington, DC: Mob. Fact Sheet (2019).

33. Perrin A, Turner E. Smartphones Help Blacks, Hispanics Close Digital Gap With Whites | Pew Research Center. Pew Research Center. Fact Tank News Numbers (2019). Available online at: https://www.pewresearch.org/fact- 
tank2019/08/20/smartphones-help-blacks-hispanics-bridge-some-but-notall-digital-gaps-with-whites/ (accessed May 4, 2021)

34. Hall CM, Bierman KL. Technology-assisted interventions for parents of young children: emerging practices, current research, future directions. Early Child Res Q. (2015) 33:21-32. doi: 10.1016/j.ecresq.2015.05.003

35. Hull P, Emerson JS, Quirk ME, Canedo JR, Jones JL, Vylegzhanina V, et al. A smartphone app for families with preschool-aged children in a public nutrition program: prototype development and beta-testing. JMIR mHealth uHealth. (2017) 5:e102. doi: 10.2196/mhealth.7477

36. Fjeldsoe BS, Miller YD, Graves N, Barnett AG, Marshall AL. Randomized controlled trial of an improved version of mobilemums, an intervention for increasing physical activity in women with young children. Ann Behav Med. (2015) 49:487-99. doi: 10.1007/s12160-014-9675-y

37. Knowlden AP, Sharma M, Cottrell RR, Wilson BR, Johnson ML. Impact evaluation of Enabling Mothers to Prevent Pediatric Obesity through Web-Based Education and Reciprocal Determinism (EMPOWER) randomized control trial. Health Educ Behav. (2015) 42:171-84. doi: $10.1177 / 1090198114547816$

38. Liberati A, Altman DG, Tetzlaff J, Mulrow C, Gøtzsche PC, Ioannidis JPA, et al. Guidelines and guidance the PRISMA statement for reporting systematic reviews and meta-analyses of studies that evaluate health care interventions: explanation and elaboration. PLoS Med. (2009) 6:e1000100. doi: 10.1371/journal.pmed.1000100

39. Hardin AP, Hackell JM, Simon GR, Boudreau ADA, Baker CN, Barden GA, et al. Age limit of pediatrics. Pediatrics. (2017) 140:e20172151. doi: 10.1542/peds.2017-2151

40. Alkhaldi G, Hamilton FL, Lau R, Webster R, Michie S, Murray E. The effectiveness of prompts to promote engagement with digital interventions: a systematic review. J Med Internet Res. (2016) 18:e6. doi: 10.2196/jmir.4790

41. Perski O, Blandford A, West R, Michie S. Conceptualising engagement with digital behaviour change interventions: a systematic review using principles from critical interpretive synthesis. Transl Behav Med. (2017) 7:254-67. doi: 10.1007/s13142-016-0453-1

42. Yardley L, Choudhury T, Patrick K, Michie S. Current issues and future directions for research into digital behavior change interventions. Am J Prev Med. (2016) 51:814-5. doi: 10.1016/j.amepre.2016.07.019

43. Cleaver K, Essex R, Malamateniou C, Narramore N, Shekede H, Vargo E, et al. A systematic scoping review and textual narrative synthesis of undergraduate pediatric nursing simulations: what, why, and how? Clin Simul Nurs. (2021) 53:10-31. doi: 10.1016/j.ecns.2020.11.008

44. Harden A, Garcia J, Oliver S, Rees R, Shepherd J, Brunton G, et al. Applying systematic review methods to studies of people's views: an example from public health research. J Epidemiol Community Health. (2004) 58:794-800. doi: 10.1136/jech.2003.014829

45. Barnett-Page E, Thomas J. Methods for the synthesis of qualitative research: a critical review. BMC Med Res Methodol. (2009) 9:59. doi: 10.1186/1471-2288-9-59

46. Popay J, Roberts H, Sowden A, Petticrew M, Arai L, Rodgers M, et al. Guidance on the Conduct of Narrative Synthesis in Systematic Reviews A Product From the ESRC Methods Programme Peninsula Medical School, Universities of Exeter and Plymouth (2006).

47. Lucas PJ, Baird J, Arai L, Law C, Roberts HM. Worked examples of alternative methods for the synthesis of qualitative and quantitative research in systematic reviews. BMC Med Res Methodol. (2007) 7:4. doi: 10.1186/1471-2288-7-4

48. Higgins JPT, Altman DG, Gotzsche PC, Juni P, Moher D, Oxman AD, et al. The Cochrane Collaboration's tool for assessing risk of bias in randomised trials. BMJ. (2011) 343:d5928. doi: 10.1136/bmj.d5928

49. Armstrong S, Mendelsohn A, Bennett G, Taveras EM, Kimberg A, Kemper AR. Texting motivational interviewing: a randomized controlled trial of motivational interviewing text messages designed to augment childhood obesity treatment. Child Obes. (2018) 14:4-10. doi: 10.1089/chi.20 17.0089

50. Baranowski T, Baranowski JC, Cullen KW, Thompson DI, Nicklas T, Zakeri IF, et al. The Fun, Food, and Fitness Project (FFFP): The Baylor GEMS Pilot study. Ethn. (2003) 13(1 Suppl. 1):S30-9.

51. Cullen KW, Thompson D, Chen TA. Outcome evaluation of family eats: an eight-session web-based program promoting healthy home food environments and dietary behaviors for African American families. Heal Educ Behav. (2017) 44:32-40. doi: 10.1177/1090198116643917

52. Frenn M, Pruszynski JE, Felzer H, Zhang J. Authoritative feeding behaviors to reduce child BMI through online interventions. J Spec Pediatr Nurs. (2013) 18:65-77. doi: 10.1111/jspn.12008

53. Haines J, McDonald J, O'Brien A, Sherry B, Bottino CJ, Schmidt ME, et al. Healthy habits, happy homes: randomized trial to improve household routines for obesity prevention among preschool-aged children. JAMA Pediatr. (2013) 167:1072-9. doi: 10.1001/jamapediatrics.2013.2356

54. Newton RL Jr, Marker AM, Allen HR, Machtmes R, Han H, et al. Parenttargeted mobile phone intervention to increase physical activity in sedentary children: randomized pilot trial. JMIR mHealth uHealth. (2014) 2:e48. doi: 10.2196/mhealth. 3420

55. Nezami BT, Ward DS, Lytle LA, Ennett ST, Tate DF. A mHealth randomized controlled trial to reduce sugar-sweetened beverage intake in preschool-aged children. Pediatr Obes. (2018) 13:668-76. doi: 10.1111/ijpo.12258

56. Robinson TN, Matheson DM, Kraemer HC, Wilson DM, Obarzanek E, Thompson NS, et al. A randomized controlled trial of culturally-tailored dance and reducing screen time to prevent weight gain in low-Income African-American girls: stanford GEMS. Arch Pediatr Adolesc Med. (2010) 164:995-1004. doi: 10.1001/archpediatrics.2010.197

57. Taveras EM, Marshall R, Sharifi M, Avalon E, Fiechtner L, Horan C, et al. Comparative effectiveness of clinical-community childhood obesity interventions a randomized clinical trial. JAMA Pediatr. (2017) 171:1-8. doi: 10.1001/jamapediatrics.2017.1325

58. Trude ACB, Surkan PJ, Steeves EA, Porter KP, Gittelsohn J. The impact of a multilevel childhood obesity prevention intervention on healthful food acquisition, preparation, and fruit and vegetable consumption on African American adult caregivers. Public Health Nutr. (2019) 22:1300-15. doi: $10.1017 / S 1368980018003038$

59. White MA, Martin PD, Newton RL, Walden HM, York-Crowe EE, Gordon ST, et al. Mediators of weight loss in a family-based intervention presented over the internet. Obes Res. (2004) 12:1050-9. doi: 10.1038/oby.20 04.132

60. Wright J, Phillips B, Watson B, Newby PK, Norman G, Adams WG. Randomized trial of a family-based, automated, conversational obesity treatment program for underserved populations. Obesity. (2013) 21:E369-78. doi: 10.1002/oby.20388

61. Martinez-Andrade GO, Cespedes EM, Rifas-Shiman SL, Romero-Quechol G, Gonzalez-Unzaga MA, Benitez-Trejo MA, et al. Feasibility and impact of Creciendo Sanos, a clinic-based pilot intervention to prevent obesity among preschool children in Mexico City. BMC Pediatr. (2014) 14:77. doi: 10.1186/1471-2431-14-77

62. Cole-Lewis H, Ezeanochie N, Turgiss J, Johnson D, Health J, Solutions W, et al. Understanding health behavior technology engagement: pathway to measuring digital behavior change interventions. JMIR Form Res. (2019) 3:14052. doi: 10.2196/14052

63. Michie S, Yardley L, West R, Patrick K, Greaves F. Developing and evaluating digital interventions to promote behavior change in health and health care: recommendations resulting from an international workshop. J Med Internet Res. (2017) 19:232. doi: 10.2196/jmir.7126

64. Griffin L, Lee D, Jaisle A, Carek P, George T, Laber E, et al. Creating an mHealth app for colorectal cancer screening: user-centered design approach. J Med Internet Res. (2019) 6:e12700. doi: 10.2196/12700

65. Sucala M, Ezeanochie NP, Cole-Lewis H, Turgiss J. An iterative, interdisciplinary, collaborative framework for developing and evaluating digital behavior change interventions. Transl Behav Med. (2020) 10:1538-48. doi: 10.1093/tbm/ibz109

66. Murray E, Hekler EB, Andersson G, Collins LM, Doherty A, Hollis C, et al. Evaluating digital health interventions: key questions and approaches. Am J Prev Med. (2016) 51:843-51. doi: 10.1016/j.amepre.2016.06.008

67. Ross J, Stevenson F, Dack C, Pal K, May C, Michie S, et al. Developing an implementation strategy for a digital health intervention: an example in routine healthcare. BMC Health Serv Res. (2018) 18:794. doi: 10.1186/s12913-018-3615-7

68. Hekler EB, Michie S, Pavel M, Rivera DE, Collins LM, Jimison HB, et al. Advancing models and theories for digital behavior change interventions. Am J Prev Med. (2016) 51:825-32. doi: 10.1016/j.amepre.2016.06.013 
69. Yardley L, Spring BJ, Riper H, Morrison LG, Crane DH, Curtis K, et al. Understanding and promoting effective engagement with digital behavior change interventions. Am J Prev Med. (2016) 51:833-42. doi: 10.1016/j.amepre.2016.06.015

70. Moller AC, Merchant G, Conroy DE, West R, Hekler E, Kugler KC, et al. Applying and advancing behavior change theories and techniques in the context of a digital health revolution: proposals for more effectively realizing untapped potential. J Behav Med. (2017) 40:85-98. doi: 10.1007/s10865-016-9818-7

71. Grady A, Barnes C, Wolfenden L, Lecathelinais C, Yoong SL. Barriers and Enablers to adoption of digital health interventions to support the implementation of dietary guidelines in early childhood education and care: cross-sectional study. J Med Internet Res. (2020) 22:e22036. doi: 10.2196/ 22036

72. Nahum-Shani I, Hekler EB, Spruijt-Metz D. Building health behavior models to guide the development of just-in-time adaptive interventions: a pragmatic framework. Health Psychol. (2015) 34S:1209-19. doi: 10.1037/hea00 00306

73. Braveman P, Egerter S, Williams DR. The social determinants of health: coming of age. Annu Rev Public Heal. (2011) 32:381-98. doi: 10.1146/annurev-publhealth-031210-101218

74. Horowitz CR, Shameer K, Gabrilove J, Atreja A, Shepard P, Goytia CN, et al. Accelerators: sparking innovation and transdisciplinary team science in disparities research. Int J Environ Res Public Health. (2017) 14:225. doi: 10.3390/ijerph14030225

75. Stokols D, Hall KL, Taylor BK, Moser RP. The science of team science overview of the field and introduction to the supplement. Am J Prev Med. (2008) 35:S77-89. doi: 10.1016/j.amepre.2008. 05.002
76. Abrams DB. Applying transdisciplinary research strategies to understanding and eliminating health disparities. Heal Educ Behav. (2006) 33:515-31. doi: $10.1177 / 1090198106287732$

77. Esparza J, Yamada T. The discovery value of "Big Science". J. Exp. Med. (2007) 204:701-4. doi: 10.1084/jem.20070073

78. Hiatt RA, Breen N. The social determinants of cancer a challenge for transdisciplinary science. Am J Prev Med. (2008) 35:S141-50. doi: 10.1016/j.amepre.2008.05.006

79. Jahan N, Naveed S, Zeshan M, Tahir MA. How to conduct a systematic review: a narrative literature review. Cureus. (2016) 8:e864. doi: 10.7759/cureus.864

80. UyBico SJ, Pavel S, Gross CP. Recruiting vulnerable populations into research: a systematic review of recruitment interventions. J Gen Intern Med. (2007) 22:852-63. doi: 10.1007/s11606-007-0126-3

81. Ford ME, Siminoff LA, Pickelsimer E, Mainous AG, Smith DW, Diaz VA, et al. Unequal burden of disease, unequal participation in clinical trials: Solutions from African American and Latino community members. Heal Soc Work. (2013) 38:29-38. doi: 10.1093/hsw/hlt001

Conflict of Interest: The authors declare that the research was conducted in the absence of any commercial or financial relationships that could be construed as a potential conflict of interest.

Copyright (c) 2021 Sanchez-Flack, Buscemi, O'Donnell, Clark Withington and Fitzgibbon. This is an open-access article distributed under the terms of the Creative Commons Attribution License (CC BY). The use, distribution or reproduction in other forums is permitted, provided the original author(s) and the copyright owner(s) are credited and that the original publication in this journal is cited, in accordance with accepted academic practice. No use, distribution or reproduction is permitted which does not comply with these terms. 